\title{
Persepsi Siswa Terhadap Fasilitas Perpustakaan Sekolah Menengah Umum Negeri 1 Bantul. \\ (Student Perception Towards Facilities Of The Library Of Public Senior High School 1 Bantul) Sidik Rokhmadi*); Anis Masruri **)
}

\begin{abstract}
This research is meant to know the student perception towards facilities of the library of public senior high school 1 Bantul. The result of this rescarch is expected to enrich the insight of the library studies, especially school library issues. This research uses a quantitative descriptive method. The subject of this research is the users of the library, students of public senior high school 1 Bantul. To achicve validity of the data, the writer uses some techniques of the data collection, namely: observation, documentation, interview, questionnaire, and library study. The result of this research shows that $63,9 \%$ of the respondents say that the library facility of public senior high school 1 Bantul is good. In terms of the building indicator, the respondents said that it is not large. It is similar to the facilities of the library by which the students percieve that they are not sufficent enough. Besides, the student perception towards the aspects of the condition and the arrangement of the facility of the school library is good and appropriate enough. Almost all kinds of library equipment are in good condition, except bag, book, and magazine shelves. Similarly, the arrangement of the library is considerd appropriate enough as 2 two kinds of equipment of the library, bag and magazine shelves, are considered still inappopriate. In order to be able to develop the quality of the library, the writer suggest that the library of the school should improve its facilities, especially the shelves. Apart from that, librarian should pay attention to the facilities.
\end{abstract}

Keyword: student perception, school library, library facility (facility of the library)

\section{ABSTRAK}

Penelitian ini bertujuan untuk mengetahui persepsi siswa terhadap fasilitas perpustakaan SMU Negeri 1 Bantul. Hasil penelitian ini diharapkan dapat menambah wawasan dalam bidang ilmu perpustakaan, khususnya perpustakaan sekolah. Penelitian ini menggunakan metode deskriptif kuantitatif, dengan subyek penelitian pemakai perpustakaan yang dalam penelitian ini adalah siswa. Untuk memperoleh data yang valid, penulis menggunakan beberapa teknik pengumpulan data yaitu observasi, dokumentasi, wawancara, angket. Hasil dari penelitian secara keseluruhan adalah fasilitas perpustakaan SMU Negeri 1 Bantul berada dalam kategori baik (63,9\%). Akan tetapi pada indikator gedung, perpustakaan sekolah ini berada dalam kategori tidak luas (70,1\%). Demikian halnya pada aspek kuantitas, fasilitas yang dimiliki perpustakaan sekolah tersebut kurang memadai $(63,3 \%)$. Selain itu, persepsi siswa terhadap fasilitas perpustakaan SMU Negeri 1 Bantul pada indikator perlengkapan (perabot) perpustakaan dalam aspek kualitas adalah baik kecuali rak penitipan (siswa yang menyatakan tidak baik sebesar 62\%), rak buku (siswa yang menyatakan tidak baik sebesar 69\%), dan rak majalah (siswa yang menyatakan tidak baik sebesar 90\%). Pada aspek penataan, perlengkapan juga berada dalam tingkat sesuai, tetapi ada 2 (dua) jenis perlengkapan yang berada dalam tingkat tidak sesuai penataannya yaitu rak penitipan (siswa yang menyatakan tidak sesuai sebesar $69 \%$ ) dan rak majalah (siswa yang menyatakan tidak sesuai sebesar 93\%). Saran untuk Perpustakaan SMU Negeri 1 Bantul yaitu perlu adanya penambahan fasilitas perpustakaan. Selain itu, pustakawan juga harus lebih memperhatikan aspek fasilitas, baik dari segi penataannya maupun perawatannya.

Kata kunci : persepsi siswa, perpustakaan sekolah, fasilitas perpustakaan

* Lulusan S I Ilmu Perpustakaan dan Informasi, Fakultas Adab UIN Sunan Kalijaga Yogyakarta

** Staf Pengajar Ilmu Perpustakaan dan Informasi, Fakultas Adab UIN Sunan Kalijaga Yogyakarta 


\section{PENDAHULUAN}

\section{A. Latar Belakang}

Pendidikan nasional diarahkan untuk meningkatkan kecerdasan kehidupan bangsa dan kualitas sumber daya manusia. Oleh karena itu dibutuhkan sumber daya-sumber daya yang berkualitas. Salah satu sumber daya pendidikan yang penting dan memerlukan perhatian adalah kualitas sumber belajar. Sumber belajar dalam lembaga pendidikan di sini adalah perpustakaan sekolah.

Perpustakaan sekolah ini bertujuan membantu dan meningkatkan pengetahuan, keterampilan, nilai, dan sikap hidup siswa dan guru dalam rangka meningkatkan mutu pendidikan secara kesuluruhan (Depdikbud dalam Ali, 1998:4). Adapun fungsi perpustakaan sekolah antara lain membantu sekolah mencapai tujuannya sesuai dengan kebijakan sekolah tempat perpustakaan tersebut bernaung (SulistyoBasuki, 1993:50-5 J). Untuk dapat mencapai tujuan dan fungsinya, perpustakaan sekolah harus dapat memanfaatkan sumber daya yang ada seperti pustakawan, dana yang tersedia, koleksi, dan fasilitas secara efektif dan efisien.

Fasilitas yang dimaksud di sini adalah sejumlah peralatan, perlengkapan, atau perabot perpustakaan yang berguna untuk melancarkan semua kegiatan perpustakaan (Darmono, 2001:213) yang meliputi papan displei, meja sirkulasi, rak penitipan, rak buku, rak majalah, rak surat kabar, meja baca dan kursi, meja belajar, katalog kabinet, rak atlas, dan rak kamus (DEPDIKNAS, 1996:14).

Begitu halnya dengan SMUN 1 Bantul sebagai salah satu lembaga pendidikan sekolah yang telah memiliki perpustakaan, tenaga perpustakaan, koleksi, dan ruang. Keberadaan perpustakaan itu perlu diketahui efisiensi dan efektivitasnya. Untuk itu antara lain dapat dilihat dari fasilitas yang dimiliki dengan cara mengetahui persepsi siswanya. Fasilitas merupakan faktor penunjang kelancaran kegiatan perpustakaan. Fasilitas yang minim akan menghambat pelaksanaan tugas pelayanan perpustakaan.

\section{B. Rumusan Masalah}

Pokok permasalahan dari penelitian ini adalah bagaimana persepsi siswa terhadap fasilitas Perpustakaan SMUN 1 Bantul tahun 2007 ?

\section{Tujuan dan Kegunaan Peneltian}

Tujuan dari penelitian ini adalah untuk mengetahui persepsi siswa terhadap fasilitas yang dimiliki oleh perpustakaan SMUN 1 Bantul pada tahun 2007. Adapun hasil penelitian ini diharapkan berguna:

1. Sebagai bahan evaluasi terhadap fasilitas Perpustakaan SMUN 1 Bantul.

2. Sebagai bahan masukan dalam meningkatkan kualitas dan kuantitas fasilitas perpustakaan di masa yang akan datang.

\section{TINJAUAN PUSTAKA}

Berdasarkan hasil penelusuran yang penulis lakukan, ditemukan empat penelitian tentang persepsi yang telah dilakukan oleh peneliti sebelumnya, yakni:

1. Ali (1998) persepsi siswa terhadap kualitas Perpustakaan Sekolah Menengah Umum Negeri 9 Bandar Lampung dan faktor-faktor apa saja yang mempengaruhi kualitas perpustakaan sekolah.

2. Handardi (2003) persepsi mahasiswa PJKR (Pendidikan Jasmani, Kesehatan, dan Rekreasi) terhadap eksistensi Laboratorium Anatomi di Fakultas Ilmu Keolahragaan Universitas Negeri Yogyakarta.

3. Suharno (2003) persepsi tentang ketersediaan sarana praktek dan motivasi belajar terhadap prestasi belajar praktikum siswa program studi audio video SMK Muhammadiyah 3 Yogyakarta. 
4. Mafar (2006) persepsi mahasiswa terhadap kualitas layanan internet di UPT perpustakaan UIN Sunan Kalijaga.

\section{LANDASAN TEORI}

\section{A. Persepsi}

Persepsi adalah proses berpikir yang dapat mewujudkan suatu pernyataan yang diinginkan seseorang terhadap suatu objek yang diamati dan sangat dipengaruhi oleh penginderaan. Persepsi yang dimaksud penulis adalah persepsi benda di mana seseorang memberikan persepsinya terhadap suatu benda yang ada di sekitarnya dalam hal ini adalah fasilitas perpustakaan.

\section{B. Siswa}

Menurut Kamus Besar Bahasa Indonesia adalah murid atau peserta didik yaitu orang (anak) yang sedang belajar, berguru, atau bersekolah terutama pada tingkat sekolah dasar dan menengah (DEPDIKNAS, 2005:765 dan 1077). Siswa, adalah manusia yang menempuh pendidikan yang merupakan subjek belajar.

\section{Perpustakaan Sekolah}

Perpustakaan sekolah adalah suatu tempat yang diperuntukkan bagi orang" yang ada di lingkungan sekolah yaitu para siswa, guru, dan karyawan. Tujuan perpustakaan sekolah ini utamanya adalah untuk menunjang proses belajar mengajar, sedangkan fungsinya adalah untuk menunjang pendidikan sekolah, sebagai suatu tempat bagi siswa dalam menambah dan mengembangkan pengetahuannya, cara belajar mandiri, dan juga sebagai wahana rekreasi melalui bahan bacaan yang tersedia di perpustakaan sekolah.

\section{Fasilitas Perpustakaan}

Fasilitas perpustakaan dapat dilihat dari aspek ruangan, perabot, dan perlengkapan. Dalam KBBI
(2005:314) Fasilitas adalah sarana untuk melancarkan pelaksanaan atau yang memberikan kemudahan. Menurut Bafadal (1994:157), perabot/ perlengkapan di sini adalah sarana atau barang-barang yang dibutuhkan dalam penyelenggaraan perpustakaan sekolah yang meliputi rak buku, rak surat kabar, rak majalah, kabinet gambar, meja sirkulasi, meja baca dan kursi, rak atau meja atlas, lemari atau kabinet katalog, kereta buku, dan papan displei.

\section{METODE PENELITIAN}

\section{A. Jenis Penelitian}

Penelitian ini merupakan penelitian deskriptif kuantitatif. Menurut Sumanto (1995:48) penelitian deskriptif adalah pengumpulan data untuk memberikan gambaran atau penegasan suatu konsep atau gejala, juga menjawab pertanyaan-pertanyaan sehubungan dengan status subjek penelitian saat ini. Berdasarkan teori tersebut, maka penelitian ini menggunakan data kuantitatif yang berupa angka-angka yang diperoleh melalui analisis skor jawaban subjek pada skala sebagaimana adanya (Arikunto, 2002:10-11).

\section{B. Subjek Penelitian}

Subjek penelitian adalah tempat di mana peneliti dapat menemukan data-data penelitian (Arikunto, 199 I: 113). Populasi dari subjek ini adalah seluruh siswa SMUN 1 Bantul yaitu sebanyak 707 siswa dan diambil sample $25 \%$, jadi sampelnya 176,75 dibulatkan menjadi 177.

\section{Metode Pengumpulan data}

\section{Dokumentasi}

Dokumentasi adalah metode pengumpulan data dengan meneliti bahan dokumentasi (Arikunto, 2002:206) 


\section{Observasi}

Observasi yaitu pengumpulan data dengan cara mengamati secara langsung terhadap objek yang diteliti dan mencatat dengan sistematis tentang fenomena-fenomena yang diselidiki (Hadi, 199:136).

\section{Wawancara}

Wawancara menurut Hadi (1992:136), yaitu pengumpulan data dengan jalan tanya jawab sepihak (peneliti) yang dilakukan secara sistematis.

\section{Angket}

Angket yaitu sejumlah pertanyaan tertulis yang digunakan untuk mendapatkan informasi dari responden dalam arti laporan tentang dirinya atau halhal yang ia ketahui (Arikunto, 2002:128).

\section{Variabel Penelitian}

Variabel adalah objek penelitian, atau apa yang menjadi titik perhatian suatu penelitian (Arikunto, 2002:96). Variabel dalam penelitian ini adalah persepsi siswa terhadap fasilitas perpustakaan dengan indikator gedung, ruangan, perabot atau perlengkapan.

\section{F. Analisis Data}

Dalam analisis data ini digunakan rumus Distribusi Frekuensi Relatif yang dikemukakan oleh Sudijono (1987:40) yaitu:

Keterangan :

$$
\mathrm{P}=\frac{f}{N} \times 100 \%
$$

f: frekuensi,

$\mathrm{N}$ : number of cases (jumlah frekuensi

atau banyaknya individu),

P: angka persentase

Dengan tolak ukur sebagai berikut:

$$
\begin{array}{ll}
0 \% & =\text { tidak satupun } \\
1 \%-25 \% & =\text { sebagian kecil } \\
26 \%-49 \% & =\text { hampir setengahnya } \\
50 \% & =\text { setengahnya }
\end{array}
$$

$$
\begin{array}{ll}
51 \%-75 \% & =\text { sebagian besar } \\
76 \%-99 \% & =\text { hampir seluruhnya } \\
100 \% & =\text { seluruhnya }
\end{array}
$$

Selain itu dalam analisa data secara keseluruhan penyusun menggunakan skala likert dengan model rating scale dg tolak ukur sebagai berikut (Riduwan dan Adkon, 2006:18).

$$
\begin{array}{ll}
1-25 \% & =\text { sangat tidak baik } \\
26-50 \% & =\text { tidak baik } \\
51-75 \% & =\text { baik } \\
76-100 \% & =\text { sangat baik }
\end{array}
$$

\section{GAMBARAN UMUM}

\section{A. Sejarah Singkat SMU 1 Bantul}

SMU Negeri 1 Bantul merupakan salah satu dari 19 SMU Negeri yang ada di Kabupaten Bantul dan merupakan sekolah tertua. SMU tersebut sudah berdiri sejak tahun 1963 dengan nama SMA Persiapan bertempat di Jl. RA. Kartini Trirenggo Bantul. Sekolah ini didirikan oleh Bapak Bupati Bantul KRT. Sosrodiningrat, Sartono dan KRT. Pringgadiningrat dan dibuka pada tanggal 17 September 1963. Sesuai SK Mendiknas tanggal 26 Oktober 1963 No. B 6181/ D2 a/ K.63 yang ditanda tangani oleh Idrus MT Hutapea, bahwa mulai tanggal 1 November 1963 SMA Persiapan ini berubah nama menjadi SMA Filial.

Pada tahun 1964 SMA Filial pindah di Jl. KHA Wakhid Hasyim telepon 367547 Palbapang Bantul 55713 Kecamatan Bantul, Kabupaten Bantul, Daerah Istimewa Yogyakarta dan menetap hingga sekarang. Tepatnya tanggal 1 Agustus 1964 SMA Filial resmi menjadi SMA Negeri 1 Bantul. Hal ini sesuai dengan SK Mendiknas tanggal 30 Juli 1964 No. 79/ SK/ D/ III yang ditanda tangani oleh Y. Basiroh. 


\section{B. Gambaran Umum Perpustakaan SMU 1 Bantul}

Perpustakaan SMU Negeri 1 Bantul merupakan salah satu sumber belajar yang berupaya melayani kebutuhan siswa. Perpustakaan ini terletak di lingkungan sekolah bagian timur dekat dengan mushola. Perpustakaan ini mempunyai luas $144 \mathrm{~m}^{2}$ $(6 \mathrm{~m} \times 24 \mathrm{~m})$.

Sistem pelayanan yang digunakan di SMU Negeri 1 Bantul adalah sistem terbuka. Melalui sistem ini pengguna dapat memilih, membaca dan mengambil sendiri buku yang dikehendaki. Pelayanan dilakukan pada hari Senin sampai hari Sabtu. Jam buka pelayanan dimulai pada pukul 07.00-15.00 WIB (khusus hari Jum'at sampai dengan jam 11.30 WIB). Pelayanan yang diberikan oleh Perpustakaan SMU Negeri 1 Bantul adalah sebagai berikut.

1. Kegiatan belajar mengajar di perpustakaan.

2. Peminjaman dan pengembalian buku.

3. Penulusuran informasi.

Adapun jumlah koleksi yang dimiliki oleh perpustakaan SMU Negeri 1 Bantul adalah sebanyak 17.123 eksemplar yang terdiri dari karya umum sebanyak 112 eks, filsafat 195 eks, agama 338 eks, ilmu sosial 2.315 eks, bahasa 2.585 eks, ilmu murni 7.911 eks, ilmu terapan $682 \mathrm{eks}$, seni dan olah raga 242 eks, kesusasteraan 1.158 eks, sejarah dan geografi 1.418 eks, referensi 152 eks, majalah 15 eks. Selain koleksi perpustakaan ini juga mempunyai berbagai fasilitas. Fasilitas yang dimiliki oleh perpustakaan tersebut adalah ruangan dengan 1 meja sirkulasi, 3 buah kipas angin, 2 buah komputer, 1 buah TV 17 inch, 10 buah meja baca, 57 kursi baca, 2 buah papan displei, berbagai macam rak (rak buku, atlas, kamus, majalah, surat kabar, dan rak penitipan) dan 1 buah katalog kabinet.

\section{KESIMPULAN}

$$
\text { Hasil dari penelitian secara }
$$

keseluruhan adalah fasilitas perpustakaan SMU Negeri 1 Bantul berada dalam kategori baik (63,9\%). Akan tetapi pada indikator gedung, perpustakaan sekolah ini berada dalam kategori tidak luas $(70,1 \%)$. Demikian halnya pada aspek kuantitas, fasilitas yang dimiliki perpustakaan sekolah tersebut kurang memadai $(63,3 \%)$. Selain itu, persepsi siswa terhadap fasilitas perpustakaan SMU Negeri 1 Bantul pada indikator perlengkapan (perabot) perpustakaan dalam aspek kualitas adalah baik kecuali rak penitipan (siswa yang menyatakan tidak baik sebesar $62 \%$ ), rak buku (siswa yang menyatakan tidak baik sebesar $69 \%$ ), dan rak majalah (siswa yang menyatakan tidak baik sebesar 90\%). Pada aspek penataan, perlengkapan juga berada dalam tingkat sesuai, tetapi ada 2 (dua) jenis perlengkapan yang berada dalam tingkat tidak sesuai penataannya yaitu rak penitipan (siswa yang menyatakan tidak sesuai sebesar $69 \%$ ) dan rak majalah (siswa yang menyatakan tidak sesuai sebesar 93\%).

Saran untuk Perpustakaan SMU Negeri 1 Bantul yaitu perlu adanya penambahan fasilitas perpustakaan. Selain itu, pustakawan juga harus lebih memperhatikan aspek fasilitas, baik dari segi penataannya maupun perawatannya.

\section{DAFTAR PUSTAKA}

Ali, Abdullah. 1998. "Persepsi Siswa Terhadap Kualitas Fasilitas dan Pelayanan Perpusatakaan Sekolah dan Faktor-faktor Yang Mempengaruhi" (Studi Kasus di Perpustakaan SMUN 9 Bandar Lampung). (Tesis). Program Studi Administrasi Negara 
Jurusan Ilmu-1lmu Sosial Program Pascasarjana Universitas Gadjah Mada Yogyakarta.

Arikunto, Suharsimi. 2002. Prosedur Penelitian: Suatu pendekatan praktek. Jakarta: Rineka Cipta.

Azra, Azyumardi. 1999. Esei-Esei Intelektual Muslim dan Pendidikan Islam. Jakarta: Logos Wacana Ilmu

Azwar, Saifuddin. 1995. Sikap Manusia: Teori dan Pengukurannya. Yogyakarta : Pustaka Pelajar.

1997. Reliabilitas dan Validitas. Yogyakarta: Pustaka Pelajar

Bafadai, Ibrahim. 1996. Pengelolaan Perpustakaan Sekolah. Jakarta: Bumi Aksara.

Budi, Setia. 2005. Persepsi Anggota Tentang Peran Pemimpin Kelompok Pada Masyarakat Miskin Kota Di Kecamatan Bogor Timur, Kota Bogor. Laporan Penelitian. Dalam http://www.damandiri.or.id/file/ setiabudiipbmetodepen.pdf tanggal 20 Februari 2007 pukul $12.10 \mathrm{WIB}$

Budiyono. 2003. "Perpustakaan Sekolah Sebagai Pusat Sumber Belajar Siswa". Dalam Makalah yang disampaikan pada Pelatihan Terintegrasi Berbasis Kompetensi Pelajaran Ekonomi bagi guru dan dosen se Indonesia pada tanggal 28, 29, 30 Okt., 4, 5 Nov. 2003 di PPPG Kesenian Yogyakarta. Kerjasama antara Departemen Pendidikan Nasional dan Perpustakaan Nasional RI.

Crews, Frederick C. The Random House Handbook. New York: Random House, Inc.

Darmono. 2001. Manajemen dan Tata Kerja Perpustakaan Sekolah. Jakarta: Gramedia Widiasarana Indonesia.

Departemen Pendidikan dan Kebudayaan. 1996. Kurikukulum Sekolah Menengah Umum (SMU): Petunjuk teknis pengelolaan perpustakaan. Jakarta: Departemen Pendidikan dan Kebudayaan Direktorat Jenderal Pendidikan Dasar dan Menengah Direktorat Pendidikan Menengah Umum.
Ghafur, Abdul. 1999. Buku Materi Pokok 4: Pengembangan Pusat Sumber Belajar (PSB) dan Kelompok Belajar. Jakarta: Universitas Terbuka.

Ghozali, Imam. 2002. Aplikasi Analisis Multivariate dengan SPSS. Semarang: Badan Penerbit Universitas Diponegoro.

Griffiths, Jillian R. 2003. "Evaluation of JISC Information Environtment: Student perception of services". http://www.informationr.net/ir/ 8-4/paper160.html/, tanggal 18 Oktober 2004, pukul 14.00 WIB.

Hadi, Sutrisno. 1995. Metodologi Research 11. Yogyakarta: Andi Offset

Handardi, Econ. 2003. "Persepsi Mahasiswa Pendidikan Jasmani Keshatan dan Rekreasi (PJKR) Terhadap Eksistensi Laboratorium Anatomi di Fakultas Ilmu Keolahragaan Universitas Negeri Yogyakarta". (Skripsi). Program Studi PJKR Fakultas Ilmu Keolahragaan Universitas Negeri Yogyakarta.

Komarudin dan Yook Tjuparman. 2000. Kamus Istilah Karya Ilmiah. Jakarta: Bumi Aksara.

Mafar, Fiqru. 2006. "Persepsi Pengguna Terhadap Pelayanan Internet di UPT UIN Sunan Kalijaga Yogyakarta Tahun 2005 (Skripsi). Program Studi Ilmu Perpustakaan Fakultas Adab UIN Sunan Kalijaga.

Marzuki. 2001. "Persepsi Para Dosen Hukum Universitas Negeri Yogyakarta tentang Pemberlakuan Hukum Pidana Islam di Indonesia" (Laporan penelitian). Fakultas Ilmu Sosial Universitas Negeri Yogyakarta

Mar'at. 1981. Sikap Manusia, Perubahan, serta Pengukuran. Jakarta: Ghalia.

Moloeng, Lexy J. 1997. Metodologi Penelitian Kualitatif. Bandung: PT. Remaja Rosdakarya.

Murianti. 1997. Organisasi, Administrasi, dan Manajemen Perpustakaan SMU. FISIPOL UGM: Proyek Pelatihan Pustakawan SMU.

Nurhadi, Mulyani Achmad. 1981. "Cara Mengevaluasi Perpustakaan Sekolah". Dalam Berita Perpustakaan Sekolah, Vol. 10, No. 3, 1981. 
Nursalam, Toha. 1996. Materi Pokok Psikologi Perpustakaan. Jakarta: Universitas Terbuka.

Pareek, Udai. 1986. Perilaku Organisasi. Jakarta: PT. Pustaka Binaman Pressindo.

Pendit, Putu Laxman. 2003. Penelitian Ilmu Perpustakaan dan Informasi: Suatu pengantar diskusi epistemologi dan metodologi. Jakarta: JEP-FSUI.

Perpustakaan Nasional R.I. 1992. Perpustakaan Sekolah: Petunjuk untuk membina, memakai dan memelihara perpustakaan di sekolah. Jakarta: Perpustakaan Nasional Republik Indonesia.

Qalyubi, Syihabuddin, dkk. 2003. Dasar-dasar Imu Perpustakaan dan Informasi. Yogyakarta: Jurusan Ilmu Perpustakaan dan Informasi Fakultas Adab IAIN Sunan Kalijaga.

Rakhmat, Jalaluddin. 1998. Psikologi Komunikasi. PT Rosdakarya. Bandung.

Ratnawati, P. 2003. Mengukur Kepuasan Masyarakat Terhadap Pelayanan Pendidikan. Dalam http:// www.depdiknas.go.id/jurnal/43/pratnawati.htm, tanggal 4 November 2006 pukul 12.43 WIB.

Riduwan dan Adkon. 2006. Rumus dan Data Dalam Aplikasi Statistik. Bandung: Alfabeta

Sardiman, A. M. 2001. Interaksi dan Motivasi BelajarMengajar. Jakarta: Rajawali Press.

Sari, Lia Artha. 2005. "Studi Deskriptif Tentang Stress Kerja Teknisi Pesawat Udara LANUD Adi Sucipto Yogyakarta." Skripsi (Tidak diterbitkan). Yogyakarta: Fakultas Psikologi Universitas Sanata Dharma.

Shaleh, A.R Ibnu Ahmad. 1987. Penyelenggaraan Perpustakaan Sekolah. Jakarta: P.T. Hidakarya Agung.

Sobur, Alex. 2003. Psikologi Umum: dalam lintasan sejarah. Bandung: Pustaka Setia.

Soehartono, Irawan. 1995. Metode Penelitian Sosial: Suatu teknik penelitian bidang kesehatan, kesejahteraan sosial, dan ilmu sosial lainnya. Bandung: Remaja Rosdakarya.
Sudijono, Anas. 1994. Pengantar Statistik Pendidikan. Jakarta: PT. RajaGrafindo Persada.

Sugiyono. 2006. Metode Penelitian Kuantitatif dan $K$ ualitatif dan $R \& D$. Bandung: Alfabeta.

Suharno. 2003. "Persepsi Ketersediaan Sarana Praktek dan Motivasi Belajar Terhadap Prestasi Belajar Praktikum Siswa Program Studi Audio Video SMK Muhammadiyah 3 Yogyakarta". (Skripsi). Jurusan Pendidikan Teknik Elektronika Fakultas Teknik Universitas Negeri Yogyakarta.

Sulistyo-Basuki. 1991. Pengantar Ilmu Perpustakaan. Jakarta: Gramedia Pustaka Utama.

1994. Periodisasi Perpustakaan Indonesia. Bandung: Remaja Rosdakarya.

Sumanto. 1995. Metodologi Penelitian Sosial Pendidikan: Aplikasi metode kuantitatif dan statistika dalam penelitian. Yogyakarta: Andi Offset.

Supardi, A. 1979. Statistik. Bandung: IAIN Sunan Gunung Jati

Thoha, Miftah. 1996. Perilaku Organisasi: Konsep dasar dan aplikasinya. Jakarta: Rajawali Persada.

Tim Penyusun Kamus Pusat Bahasa. 2005. Kamus Besar Bahasa Indonesia. Jakarta: Balai Pustaka.

Walgito, Bimo. 1972. Psikologi Sosial (Suatu Pengantar). Yogyakarta: Andi Offset.

Young, K. 1995. Social Psychology. New York: Appleton Cenory Crofts Inc. 